\title{
The Values of First-trimester Maternal Serum Markers in Predicting Poor Obstetric Outcomes
}

\author{
İlk Trimester Maternal Serum Belirteçlerinin Kötü Obstetrik Sonuçları Öngörmede \\ Değeri
}
(D) Șafak Yılmaz Baran, (D) Hakan Kalaycı, (D) Gülșen Doğan Durdağ, (D) Seda Yüksel şimşek, (D) Selçuk Yetkinel, (D) Erhan Şimşek

Bașkent University Adana Dr. Turgut Noyan Training and Research Center, Department of Obstetrics and Gynaecology, Adana, Turkey

\begin{abstract}
Introduction: The effects of pregnancy-associated plasma protein A (PAPP-A) and maternal serum free beta-human chorionic gonadotropin $(\beta-\mathrm{hCG})$, which are first trimester maternal serum markers, on assisting in the diagnosis of chromosomal abnormalities and perinatal outcome are discussed. The aim of the presented study was to investigate the predictive value of first-trimester PAPP-A and $\beta$-hCG) levels in predicting poor obstetric outcomes.
\end{abstract}

Methods: A total of 549 patients who underwent first trimester screening in Perinatalogy Outpatient Clinic of our hospital between January 2016 and March 2018 were included in this study. Patients with crown-rump length (CRL) measurements in the range of 45-84 $\mathrm{mm}$, patients with singleton pregnancy and patients who delivered at 24 weeks or later were included in the study. CRL, nuchal translucency, mean uterine artery pulsatility index, PAPP-A and free $\beta$-hCG levels were recorded. The 5th and 10th percentile values of PAPP-A and free $\beta$-hCG levels were designated according to the literature.

Results: There was no difference between PAPP-A percentile groups in terms of mean birth weight or gestational age at delivery. However, mean gestational age at delivery was lower in patients with free $\beta$-hCG levels below 10th percentile. Preterm delivery was significantly higher in the group with PAPP-A levels below 5 th percentile $(p=0.049)$. Also, preeclampsia $(P E)$ was higher in the group with free $\beta$-hCG below 10th percentile $(\mathrm{p}=0.003)$.

Conclusion: The risk poor obstetric outcome such as preterm delivery, low birth weight and PE may be associated with low PAPP-A and free $\beta$-hCG levels. However, further studies are needed to explain the relationship between first trimester screening markers and neonatal outcomes.

Keywords: Pregnancy-associated plasma protein A, beta HCG, preeclampsia, preterm delivery

\section{ÖZ}

Amaç: illk trimester maternal serum belirteçlerinden olan Gebelikle ilișkili plazma proteini-A (PAPP-A) ve maternal serum free beta-insan koryonik gonadotropin ( $s \beta-h C G)$ düzeylerinin kromozomal anomalilerin tanısına yardımcı olmanın dışında perinatal sonuçlar üzerine etkileri üzerinde durulmaktadır. Çalışmamızın amacı ilk trimester PAPP-A ve $s \beta$-hCG düzeylerinin kötü obstetrik sonuçları öngörebilmedeki değerini incelemektir.

Yöntemler: Çalıșmamıza, ilk trimester taramasını Ocak 2016-Mart 2018 yılları arasında hastanemiz Perinataloji Polikliniği'nde yaptırmış 549 hasta dahil edilmiştir. Ultrasonografik taramada fetüs baş-pop uzunluğu (CRL) ölçümü 45-84 mm aralığında olan, tekil, 24 hafta ve üzerinde doğum yapmış olan hastalar çalıșmaya alınmıștır. CRL, nukal kalınlık, ortalama uterin arter pulsatilite indeks ölçümleri ve PAPP-A, $s \beta$-hCG değerleri kaydedilmiștir. Literatüre göre PAPP-A ve $s \beta$-hCG'nin 5. ve 10. persentil değerleri düzenlenmiștir.

Bulgular: PAPP-A persentil grupları ile ortalama doğum kilosu veya ortalama doğum haftası arasında bir ilişki bulunmamıştır. Bunun yanında s $\beta$-hCG'nin 10 . persentil altı düzeylerinde ortalama doğum haftasının daha düşük olduğu izlenmiștir. PAPP-A'nın 5. persentil altı düzeylerinde preterm doğum oranı daha sık $(p=0,049)$ ve $s \beta$-hCG'nin 10. persentil altı düzeylerinde preeklampsinin belirgin olarak yüksek oranda görüldügü izlenmiştir ( $p=0,003)$.

Sonuç: Preterm doğum, düşük doğum ağırlığı ve preeklampsi gibi kötü obstetrik sonuç gelișme riski düșük PAPP-A ve s $\beta$-hCG düzeyleri ile ilişkili olabilir. Yine de, ilk trimester tarama belirteçleri ile obstetrik sonuçlar arasındaki ilişkiyi açıklayabilmek için çok sayıda çalıșmaya ihtiyaç duyulmaktadır. Anahtar Kelimeler: PAPP-A, beta HCG, preeklampsi, preterm doğum
Address for Correspondence/Yazıșma Adresi: Șafak Yılmaz Baran MD, Başkent University Adana Dr. Turgut Noyan Training and Research Center, Department of Obstetrics and Gynaecology, Adana, Turkey

Phone: +90 3224586868 E-mail: safakyilmazbaran@gmail.com ORCID ID: orcid.org/0000-0001-5874-7324

Cite this article as/Atıf: Baran ȘY, Kalaycı H, Doğan Durdağ G, Yüksel Şimşek S, Yetkinel S, Şimşek E. The Values of First-trimester Maternal Serum Markers in Predicting Poor Obstetric Outcomes. İstanbul Med J 2019; 20(4): 325-9.
Received/Geliș Tarihi: 13.01.2019 Accepted/Kabul Tarihi: 04.05.2019

(c) Copyright 2019 by the Istanbul Training and Research Hospital/Istanbul Medical Journal published by Galenos Publishing House.

(C) Telif Hakkı 2019 Istanbul Ĕgitim ve Araștırma Hastanesi/Istanbul Tıp Dergisi, Galenos Yayınevi tarafından basılmıștır. 


\section{Introduction}

First trimester screening has a paramount importance to reveal anomalies in the fetus. The combination of maternal age, nuchal translucency (NT), maternal serum free beta-human chorionic gonadotropin (free $\beta$-hCG) and pregnancy-associated plasma protein A (PAPP-A) identifies trisomy-21 with an $85 \%$ detection rate with a $5 \%$ false positivity $(1,2)$. Also, some studies have shown a relationship between Iow PAPP-A and free $\beta$-hCG levels in the $11-13^{\text {th }}$ weeks of gestation with poor obstetric outcomes such as stillbirth, fetal growth restriction (FGR), preterm delivery and preeclampsia (PE) (3-7).

PAPP-A is an insulin-like growth factor binding protein-4 (IGFBP-4) protease, which is secreted by trophoblasts and decidual cells. Low PAPP-A levels decrease the IGF levels by increasing the IGFBP-4 level. IGF is a stimulant molecule for fetal growth and maturity (8). Meanwhile, free $\beta$-hCG is secreted by syncytiotrophoblasts of the placenta in addition to the corpus luteum of the ovary in early pregnancy and it promotes angiogenesis, and its secretion increases under different conditions such as uteroplacental insufficiency (9).

The aim of the presented study was to investigate the predictive value of first trimester PAPP-A and free $\beta$-hCG levels for poor obstetric outcomes. Although different cut-off values have been proposed in the literature, we took the $5^{\text {th }}$ and $10^{\text {th }}$ percentile ranks of FASTER study to detect the effect of PAPP-A and free $\beta$-hCG levels on obstetric outcomes (5).

\section{Methods}

The study cohort consisted of pregnant women who underwent first trimester screening in our Perinatology Clinic between January 2016 and March 2018. The medical records were evaluated retrospectively and 549 patients were included in the study. Patients with crownrump length (CRL) measurement between 45 and $84 \mathrm{~mm}$, patients with singleton pregnancy and patients who delivered at 24 weeks or later were included.

A single operator performed all ultrasonographic evaluations with a 5-8 MHz 3D transducer ultrasound system (General Electric Voluson E8 ${ }^{\mathrm{TM}}, \mathrm{GE}$ Healthcare, Chicago, Illinois, United States) via transabdominal route. All maternal variables such as age, height, weight, body mass index, gravidity and parity were recorded. Also, CRL measurements with the concordant gestational week, NT, mean uterine artery pulsatility index, PAPP-A and free $\beta$-hCG levels were noted.

PAPP-A and free $\beta$-hCG levels were measured by chemiluminescent immunometric assay from blood samples of pregnant women using Immulite 2000 XP device (Siemens A6 Healthcare Sector, Erlangen, Germany). These indicators were converted into multiples of the expected median (MoM) value with PRISCA 5.0 software considering the maternal age, medical history and patient-specific factors. The $5^{\text {th }}$ and $10^{\text {th }}$ percentile ranks of PAPP-A and free $\beta$-hCG values were determined according to FASTER study and groups were constructed amongst these values to compare the possible differences of preterm delivery, low birth weight (LBW) and PE between groups (5).

According to the World Health Organization, preterm delivery is accepted as labor before $37^{\text {th }}$ weeks of pregnancy. According to the
American College of Gynecologists, LBW is accepted as $<2500$ gr live birth. PE criteria were as follows: hypertension (systolic pressure $\geq 140$ $\mathrm{mmHg}$ /diastolic pressure $\geq 90 \mathrm{mmHg}$ ) starting after $20^{\text {th }}$ gestational week and accompanied by proteinuria ( $\geq 300 \mathrm{mg}$ proteinuria in 24 hours or rate of protein/creatinine $>0.3$ ) or end organ dysfunction (platelet count $<100000 / \mathrm{mL}$ or serum creatinine level $\geq 1.1 \mathrm{mg} / \mathrm{dL}$ or two-fold increase in serum transaminase levels). Adana Dr. Turgut Noyan University, Non-interventional Clinical Research Ethics Committee (decision no: KA18/187).

\section{Statistical Analysis}

All recorded values such as maternal characteristics, correlation between birth weight and gestational age at delivery between pregnancy groups according to $5^{\text {th }}$ and $10^{\text {th }}$ percentile values of PAPP-A (0.42 MoM/0.52 MoM) and free $\beta$-hCG (0.35 MoM/0.44MoM) were analyzed with SPSS version 21 software package. Categorical variables were expressed as number and percentage, and constant variables were expressed mean and standard deviation (median and range, where necessary). Student's t-test for constant variables and Fisher's Exact test for categorical variables were used to compare baseline characteristics and perinatal outcomes. Spearman correlation analysis was used to describe the relationship between gestational age at delivery, birth weight and PAPP-A and free $\beta$-hCG levels. Presence of PE was evaluated with Mann-Whitney $U$ test between groups. A p value of $<0.05$ was accepted as significant in all statistical analysis.

\section{Results}

A total of 736 records were evaluated and it was realized that 170 patients were lost during follow-up. Also, five pregnancies were terminated due to congenital anomalies, nine patients had stillbirth before $20^{\text {th }}$ gestational week and one patient delivered at $23^{\text {rd }}$ gestational week, so these patients were excluded. All patients excluded from the analysis had a PAPP-A and free $\beta$-hCG levels above $10^{\text {th }}$ percentile, but one intrauterine ex fetus ( $14^{\text {th }}$ gestational week) had a low PAPPA level $(0.26$ MoM). Consequently, a total of 549 patients were included in the study. The maternal characteristics and evaluated variables are presented in Table 1. Table 2 shows the patients having PAPP-A or free $\beta$-hCG below $5^{\text {th }}$ and $10^{\text {th }}$ percentiles.

The indications for preterm delivery were PE, preterm premature rupture of membrane, spontaneous preterm birth, acute fetal distress, chorioamnionitis, abruptio placenta, fetal cardiac anomaly and maternal decompensated cardiac failure.

According to our retrospective calculations, PAPP-A had a power of $\% 95$ for preterm delivery/PE comparison and free $\beta$-hCG had a power of $100 \%$ for PE comparison.

We did not find any significant difference between PAPP-A percentile groups in terms of mean birth weight $\left(5^{\text {th }}\right.$ and $10^{\text {th }}$ percentile, $p=0.243$ and $p=0.139$, respectively) or gestational age at delivery ( $5^{\text {th }}$ and $10^{\text {th }}$ percentile, $p=0.229$ and $p=0.523$ respectively). However, there was a statistically significant difference between free $\beta$-hCG percentile groups regarding mean gestational age at delivery ( $5^{\text {th }}$ percentile $p=0.013$ and $10^{\text {th }}$ percentile $p=0.037$ ). There was no difference in birth weights 
according to free $\beta$-hCG levels ( $5^{\text {th }}$ percentile $p=0.232$ and $10^{\text {th }}$ percentile $p=0.778)$.

The rate of LBW, preterm delivery and PE were 5.5\% $(n=30), 6.9 \%(n=38)$ and $7.8 \%(n=43)$ in entire cohort, respectively. Only preterm delivery was significantly higher in PAPP-A below $5^{\text {th }}$ percentile group $(p=0.049)$. However, no significant cut-off value was obtained by ROC analysis. Also, PE was higher in free $\beta$-hCG groups below the $5^{\text {th }}$ and $10^{\text {th }}$ percentiles ( $p=0.032$ and $p=0.003$, respectively). ROC analysis for relationship between free $\beta$-hCG levels and PE revealed an AUC of 0.6 (0.5-0.7, 95\% Cl). A cut-off value of 0.765 MoM for free $\beta$-hCG (64\% sensitivity, $53.5 \%$ specificity, $11.2 \%$ negative predictive value and $63.2 \%$ positive predictive value) was determined for the prediction of $\mathrm{PE}(\mathrm{p}=0.03)$.

SGA and PE were detected at a rate of $50 \%(n=19)$ and $29 \%(n=11)$ in all preterm deliveries $(n=38)$, respectively. The relationship between maternal serum PAPP-A and free $\beta$-hCG values above and below $5^{\text {th }}$ and $10^{\text {th }}$ percentiles with mean gestational age at delivery, weight and adverse perinatal outcomes are presented in Table 3.

\section{Discussion}

According to our results, the rate of preterm delivery was higher in lower percentiles of PAPP-A and the rate of PE was higher in the lower percentiles of free $\beta$-hCG. Preterm delivery is considered as a result of the suboptimal intrauterine environment, which causes FGR. The higher prevalence of preterm deliveries with low PAPP-A in our cohort might be affected by the presence of LBW babies in this group (10).

There is a controversy in the literature about the use of first trimester NT, PAPP-A and free $\beta$-hCG measurements, alone or in a combination, to estimate birth weight, gestational age at delivery and perinatal outcomes

Table 1. The maternal characteristics, first trimester screening variables and mean gestational age at delivery/weight

\begin{tabular}{|l|l|l|l|l|}
\hline & $\mathbf{n}$ & mean $( \pm$ SD) & minimum-maximum \\
\hline Maternal age & 549 & $30.4( \pm 4.7)$ & $18-45$ \\
\hline Gravidity/parity & 549 & $2 / 1$ & $1-9 / 0-4$ \\
\hline BMI $\left(\mathrm{kg} / \mathrm{m}^{2}\right)$ & 509 & $24.2( \pm 4.2)$ & $15.5-46$ \\
\hline Gestational age & 549 & $60( \pm 7.35)$ & $11^{+2}-14 \mathrm{~W}$ \\
\hline CRL $(\mathrm{mm})$ & 549 & $1.6( \pm 0.33)$ & $45-82$ \\
\hline NT $(\mathrm{mm})$ & 547 & $1.90( \pm 0.6)$ & $1-2.6$ \\
\hline Mean uterine artery PI & 462 & $1.07( \pm 0.6)$ & $0.71-5.27$ \\
\hline PAPP-A (MoM) & 549 & $1.18( \pm 0.96)$ & $0.17-3.53$ \\
\hline Free $\beta$-hCG (MoM) & 549 & $38^{+4} \mathrm{~W}( \pm 1.4)$ & $0.15-14.5$ \\
\hline Gestational age at delivery & 549 & $3306( \pm 500)$ & $28^{+3}-41^{+1} \mathrm{~W}$ \\
\hline Birth weight (g) & 549 & $1050-5000$ \\
\hline SD: standard devian & \\
\hline
\end{tabular}

SD: standard deviation; BMI: body mass index; CRL: crown-rump length; NT: nuchal translucency; PI: pulsatility index; PAPP-A: pregnancy-associated plasma protein A, MoM: multiples of median, $\beta$-hCG: beta-human chorionic gonadotropin

Table 2. The evaluation of the patient groups in the $<5^{\text {th }}$ percentile and $<10^{\text {th }}$ percentile groups of PAPP-A and free $\beta$-hCG

\begin{tabular}{l|l|l|l|l|} 
& PAPP-A (MoM) & $\mathbf{n}(\%)$ & Free $\beta$-hCG (MoM) & $\mathbf{n}(\%)$ \\
\hline$<5^{\text {th }}$ centile & 0.42 & $40(7.3 \%)$ & 0.35 & $24(4.4 \%)$ \\
\hline$<10^{\text {th }}$ centile & 0.52 & $75(13.6 \%)$ & 0.44 & $67(12.2 \%)$ \\
\hline PAPP-A: pregnancy-associated plasma protein A, MoM: multiples of median, $\beta$-hCG: beta-human chorionic gonadotropin
\end{tabular}

Table 3. The relationship between maternal serum PAPP-A and free $\beta$-hCG values with mean gestational age at delivery, weight and adverse perinatal outcomes in groups according to $5^{\text {th }}$ and $10^{\text {th }}$ percentiles

\begin{tabular}{|c|c|c|c|c|c|c|c|c|c|c|}
\hline & $\begin{array}{l}\text { Mean birth } \\
\text { weight, (g) }\end{array}$ & $\mathbf{p}$ & $\begin{array}{l}\text { Mean } \\
\text { gestational age } \\
\text { at delivery }\end{array}$ & $\mathbf{p}$ & LBW, n (\%) & $\mathbf{p}$ & $\begin{array}{l}\text { Preterm } \\
\text { delivery } \\
\mathrm{n}(\%)\end{array}$ & $\mathbf{p}$ & $\begin{array}{l}\text { Preeclampsia, } \\
\text { n (\%) }\end{array}$ & $\mathbf{p}$ \\
\hline PAPP-A $<5^{\text {th }}$ & 3213 & \multirow{2}{*}{0.243} & $37 w 6 d$ & \multirow{2}{*}{0.229} & $1(2.5 \%)$ & \multirow[t]{2}{*}{0.715} & $6(15 \%)$ & \multirow{2}{*}{0.049} & $5(12.5 \%)$ & \multirow{2}{*}{0.228} \\
\hline$P A P P-A \geq 5^{\text {th }}$ & 3313 & & $38 w 2 d$ & & $29(5.7 \%)$ & & $32(6.3 \%)$ & & $38(7.5 \%)$ & \\
\hline PAPP-A $<10^{\text {th }}$ & 3244 & \multirow{2}{*}{0.139} & $38 w 2 d$ & \multirow{2}{*}{0.523} & $2(2.7 \%)$ & \multirow[t]{2}{*}{0.409} & $7(9.3 \%)$ & \multirow{2}{*}{0.336} & $9(12 \%)$ & \multirow{2}{*}{0.164} \\
\hline PAPP-A $\geq 10^{\text {th }}$ & 3315 & & $38 w 4 d$ & & $28(5.9 \%)$ & & $31(6.5 \%)$ & & $34(7.2 \%)$ & \\
\hline Free $\beta$-hCG $<5^{\text {th }}$ & 3208 & \multirow{2}{*}{0.232} & $37 w 6 d$ & \multirow{2}{*}{0.013} & $1(4.2 \%)$ & \multirow{2}{*}{1} & $3(12.5 \%)$ & \multirow{2}{*}{0.227} & $5(20.8 \%)$ & \multirow{2}{*}{0.032} \\
\hline Free $\beta-h C G \geq 5^{\text {th }}$ & 3310 & & $38 w 3 d$ & & $29(5.5 \%)$ & & $35(6.7 \%)$ & & $38(7.2 \%)$ & \\
\hline Free $\beta$-hCG $<10^{\text {th }}$ & 3267 & \multirow{2}{*}{0.778} & $38 w 0 d$ & \multirow{2}{*}{0.037} & $4(6 \%)$ & \multirow{2}{*}{0.776} & $6(9 \%)$ & \multirow{2}{*}{0.445} & $12(17.9 \%)$ & \multirow{2}{*}{0.003} \\
\hline Free $\beta$-hCG $\geq 10^{\text {th }}$ & 3311 & & $38 w 4 d$ & & $26(5.4 \%)$ & & $32(6.6 \%)$ & & $31(6.4 \%)$ & \\
\hline
\end{tabular}

PAPP-A: pregnancy-associated plasma protein A; $\beta$-hCG: beta-human chorionic gonadotropin; LBW: low birth weight 
(1,11-13). Poon and Nicolaides stated that PAPP-A, placental growth factor and uterine artery Doppler measurements, in combination with first trimester maternal risk factors, predict early onset PE with a rate of $95 \%$ (14). Dugoff et al, in their multicenter FASTER study, defined the percentile ranks of MoM values with the combination of first trimester NT, PAPP-A, and free $\beta$-hCG measurements in a cohort of 33.395 pregnant women. Their results showed that a level of PAPP-A $\leq 10^{\text {th }}$ percentile indicated almost 2.5 -fold higher risk for LBW and correlation with poor obstetric outcomes. For free $\beta$-hCG levels, they identified a relationship with spontaneous loss below $24^{\text {th }}$ weeks of gestation in $\leq 1^{\text {st }}$ percentile group (5). Covans and Spencer supported the results of the FASTER study in their study, which confirmed the relationship between low PAPP-A levels and LBW (15). Also, Kaijomaa et al. compared groups with PAPP-A $<0.3 \mathrm{MoM}$ and PAPP-A $\geq 0.3 \mathrm{MoM}$, and they stated that low PAPP-A values indicated poor obstetric outcomes (16). Our results did not demonstrate any association with mean gestational age at delivery, weight, LBW and PE at low values of PAPP-A, yet we only found that the preterm delivery rate increased with PAPP-A levels below $5^{\text {th }}$ percentile $(<0.42 \mathrm{MoM})$.

Similarly, conflicting results have been published about the relationship between low levels of free $\beta$-hCG in the first trimester and poor pregnancy outcomes. Sirikunalai et al. reviewed 13.620 singleton pregnancies and summarized in their study that free $\beta$-hCG $<0.5$ MoM value was associated with FGR, preterm delivery, LBW and low APGAR scores (17). Nevertheless, another study did not show a similar relationship between $\beta$-hCG at first or second trimester and FGR and PE, but reported that second trimester intact hCG $>3$ MoM might predict FGR. The authors concluded that the placental dysfunction might lead to pregnancy complications such as FGR or PE (18). In our cohort, the rate of PE was higher in the lower percentiles of free $\beta$-hCG. Extreme levels of free $\beta$-hCG may be considered as a marker for prenatal surveillance of pregnancies.

Two studies from our country showed contradictory results. In the first study with 318 singleton pregnancies, no significant relationship was found between low PAPP-A levels and incidence of subsequent pregnancy outcomes (19). In the other study, there was a correlation between low PAPP-A levels ( $\leq 0.35 \mathrm{MoM})$ and preterm delivery, low mean birth weight and low gestational age at delivery. However, low free $\beta$-hCG levels were not associated with measured variables (20). In our study, the lower percentiles of free $\beta$-hCG were associated with lower gestational age at delivery. On the contrary, such a correlation could not be demonstrated between lower PAPP-A percentiles and birth weight or gestational age at delivery.

Sonek et al. stated that first trimester markers in combination with maternal characteristics predicted early or late onset PE with a high detection rate and a low false positive rate (21). Similarly, we found a relationship between low free $\beta$-hCG levels and PE.

On the other hand, there are many studies in the literature stating that PAPP-A levels were not helpful in predicting poor obstetric outcomes (22-24). In our study, however, there was an increase in preterm delivery in low PAPP-A group and the difference was statistically significant. We did not reach any conclusions to accept the null hypothesis since the effect seemed limited. On the other hand, considering literature and our results, pregnancies with a level of PAPP-A below $5^{\text {th }}$ percentile and free $\beta$-hCG do not require exceptional monitoring (25).

Our study has some limitations, including (i) retrospective nature, (ii) lack of interpretation of possible covariates, and (iii) lack of evaluation of comprehensive obstetric outcomes (diabetes mellitus, placental pathologies, etc.).

The main difficulty in making a definitive conclusion on this topic is the heterogeneity of the cohorts and methodological differences between the studies in the literature. In addition, different measurement techniques, experiences, thresholds and analysis methods lead to inconsistent outcomes (11,12, 21, 26-28). Considering the literature, more studies with larger cohorts are needed to establish nomograms in the pregnant population.

\section{Conclusion}

Early pregnancy markers such as NT, PAPP-A or free $\beta$-hCG, alone or in combination, seem unsatisfactory to predict adverse pregnancy outcomes. The clinical implication of these markers should have better positive predictive values and coherent understanding of the mechanisms of the pathophysiological process of the poor obstetric outcomes. Further studies are needed to explain the relationship between first trimester screening markers and neonatal outcomes while considering possible covariates.

Ethics Committee Approval: Adana Dr. Turgut Noyan University, Non-interventional Clinical Research Ethics Committee (decision no: KA18/187).

Informed Consent: Retrospective study.

Peer-review: Externally peer-reviewed.

Author Contributions: Concept - S.Y.B., H.K., G.D.D., S.Y.S., S.Y.; Design - S.Y.B., H.K., S.Y.S., S.Y.; Data Collection and/or Processing - S.Y.B., G.D.D., S.Y.; Analysis and/or Interpretation - S.Y.B., G.D.D., S.Y.Ş., S.Y., E.S.; Literature Search - Ş.Y.B.; Writing Manuscript - Ş.Y.B., H.K., G.D.D.

Conflict of Interest: No conflict of interest was declared by the authors.

Financial Disclosure: The authors declared that this study received no financial support.

\section{References}

1. Lüthgens K, Merz E, Hackelöer BJ, Thode C, Eiben B, Kagan KO. Comparison of three first trimester screening algorithms for trisomy 21 with and without adjustment for maternal characteristics. Ultraschall Med 2013; 34: 151-6.

2. Palomaki GE, Lambert-Messerlian GM, Canick JA. A summary analysis of down syndrome markers in the late first trimester. Adv Clin Chem 2007; 43: 177-210.

3. Proctor LK, Toal M, Keating S, Chitayat D, Okun N, Windrim RC, et al. Placental size and the prediction of severe early-onset intrauterine growth restriction in women with low pregnancy-associated plasma protein-A. 2009; 34: 274-82.

4. Gagnon A, Wilson RD; Society of Obstetricians and Gynaecologists of Canada Genetics Committee. Obstetrical complications associated with abnormal maternal serum markers analytes. J Obstet Gynaecol Can 2008; 30: 918-32.

5. Dugoff L, Hobbins JC, Malone FD, Porter TF, Luthy D, Comstock CH, et al. Firsttrimester maternal serum PAPP-A and free-beta subunit human chorionic gonadotropin concentrations and nuchal translucency are associated with 
obstetric complications: a population-based screening study (the FASTER Trial). Am J Obstet Gynecol 2004; 191: 1446-51.

6. Krantz D, Goetzl L, Simpson JL, Thom E, Zachary J, Hallahan TW, et al. Association of extreme first-trimester free human chorionic gonadotropinbeta, pregnancy-associated plasma protein A, and nuchal translucency with intrauterine growth restriction and other adverse pregnancy outcomes. Am J Obstet Gynecol 2004; 191: 1452-8.

7. Smith GC, Crossley JA, Aitken DA, Pell JP, Cameron AD, Connor JM, et al. Firsttrimester placentation and the risk of antepartum stillbirth. JAMA 2004; 292: 2249-54.

8. Lawrence JB, Oxvig C, Overgaard MT, Sottrup-Jensen L, Gleich GJ, Hays LG, et al. The insulin-like growth factor (IGF)-dependent IGF binding protein-4 protease secreted by human fibroblasts is pregnancy-associated plasma protein-A. Proc Natl Acad Sci U S A. 1999; 96: 3149-53.

9. Pijnenborg R, Dixon G, Robertson WB, Brosens I. Trophoblastic invasion of human decidua from 8 to 18 weeks of pregnancy. Placenta 1980; 1: 3-19.

10. Kirkegaard I, Uldbjerg N, Petersen OB, Tørring N, Henriksen TB. PAPP-A, free $\beta$-hCG, and early fetal growth identify two pathways leading to preterm delivery. Prenat diagn. 2010; 30: 956-63.

11. Poon LC, Karagiannis G, Staboulidou I, Shafiei A, Nicolaides KH. The reference range of birth weight with gestation and first-trimester prediction of smallfor-gestation neonates. Prenat Diagn 2011; 31: 58-65.

12. Montanari L, Alfei A, Albonico G, Moratti R, Arossa A, Beneventi F, et al. The impact of first-trimester serum free beta-human chorionic gonadotropin and pregnancy-associated plasma protein A on the diagnosis of fetal growth restriction and small for gestational age infant. Fetal Diagn Ther. 2009; 25: 130-5.

13. Plasencia W, González Dávila E, Tetilla V, Padrón Péréz E, Garcia Hernández JA, González González NL. First-trimester screening for large-for-gestationalage infants. Ultrasound in obstetrics \& gynecology: the official journal of the International Society of Ultrasound in Obstetrics and Gynecology. 2012; 39: 389-95.

14. Poon LC, Nicolaides KH. First-trimester maternal factors and biomarker screening for preeclampsia. Prenatal diagnosis. 2014; 34: 9-17.

15. Cowans NJ, Spencer K. First-trimester ADAM12, and PAPP-A as markers for intrauterine fetal growth restriction through their roles in the insulin-like growth factor system. Prenat Diagn 2007; 27: 264-71.

16. Kaijomaa M, Rahkonen L, Ulander VM, Hämäläinen E, Alfthan H, Markkanen $\mathrm{H}$, et al. Low maternal pregnancy-associated plasma protein a during the first trimester of pregnancy and pregnancy outcomes. International journal of gynecology and obstetrics: the official organ of the International Federation of Gynaecology and Obstetrics. 2017; 136: 76-82.
17. Sirikunalai P, Wanapirak C, Sirichotiyakul S, Tongprasert F, Srisupundit K, Luewan $S$, et al. Associations between maternal serum free beta human chorionic gonadotropin ( $\beta$-hCG) levels and adverse pregnancy outcomes. J Obstet Gynaecol 2016; 36: 178-82.

18. Sharony R, Sharon-Weiner M, Kidron D, Sukenik-Halevy R, Biron-Shental T, Manor $\mathrm{M}$, et al. The association between maternal serum first trimester free $\beta \mathrm{hCG}$, second trimester intact hCG levels and foetal growth restriction and preeclampsia. J Obstet Gynaecol 2018; 38: 363-66.

19. Saruhan Z, Ozekinci M, Simsek M, Mendilcioglu I. Association of first trimester Iow PAPP-A levels with adverse pregnancy outcomes. Clin Exp Obstet Gynecol 2012; 39: 225-8.

20. Dane B, Dane C, Batmaz G, Ates S, Dansuk R. First trimester maternal serum pregnancy-associated plasma protein-A is a predictive factor for early preterm delivery in normotensive pregnancies. Gynecol Endocrinol 2013; 29: 592-5.

21. Sonek J, Krantz D, Carmichael J, Downing C, Jessup K, Haidar Z, et al. First-trimester screening for early and late preeclampsia using maternal characteristics, biomarkers, and estimated placental volume. Am J Obstet Gynecol 2018; 218: 1-13

22. Quattrocchi T, Baviera G, Pochiero T, Basile F, Rizzo L, Santamaria A, et al. Maternal serum PAPP-A as an early marker of obstetric complications? Fetal diagnosis and therapy. 2015; 37: 33-6.

23. Patil M, Panchanadikar TM, Wagh G. Variation of Papp-A level in the first trimester of pregnancy and its clinical outcome. J Obstet Gynecol. 2013; 64: 116-9.

24. Boucoiran I, Djemli A, Taillefer C, Rypens F, Delvin EE, Audibert F. Firsttrimester prediction of birth weight. American Journal of Perinatology 2013; 30: 665-72.

25. Van Ravenswaaij R, Tesselaar-van der Goot M, de Wolf S, van LeeuwenSpruijt M, Visser GH, Schielen PC. First-trimester serum PAPP-A and f betahCG concentrations and other maternal characteristics to establish logistic regression-based predictive rules for adverse pregnancy outcome. Prenat Diagn 2011; 31: 50-7.

26. Wagner P, Sonek J, Klein J, Hoopmann M, Abele H, Kagan KO. First-trimester ultrasound screening for trisomy 21 based on maternal age, fetal nuchal translucency, and different methods of ductus venosus assessment. Prenat Diagn 2017; 37: 680-5

27. Pihl K, Sorensen TL, Norgaard-Pedersen B, Larsen SO, Nguyen TH, Krebs L, et al. First-trimester combined screening for Down syndrome: prediction of low birth weight, small for gestational age and pre-term delivery in a cohort of non-selected women. Prenat Diagn 2008; 28: 247-53.

28. Kuc S, Wortelboer EJ, Koster MP, de Valk HW, Schielen PC, Visser GH. Prediction of macrosomia at birth in type- 1 and 2 diabetic pregnancies with biomarkers of early placentation. BJOG 2011; 118: 748-54. 